Revista de

Contabilidade e Organizações

www.rco.usp.br
DOI: http://dx.doi.org/10.11606/issn.1982-6486.rco.2021.174007
Journal of

Accounting and

Organizations

\title{
Does capital structure influence the performance of corporate social responsibility? An analysis in companies of the world's largest economies
}

\author{
A estrutura de capital influencia a responsabilidade social corporativa? Uma análise das companhias nas \\ maiores economias do mundo
}

Paula Pontes de Campos-Rasera ${ }^{\mathrm{a}}$, Gabriela de Abreu Passos ${ }^{\mathrm{b}}$, Romualdo Douglas Colauto ${ }^{\mathrm{a}}$

${ }^{a}$ Universidade Federal do Paraná - Brazil

${ }^{b}$ Universidade de Brasilia - Brazil

\section{Keywords}

Corporate social responsibility.

Capital structure.

Debt.

Equity.

GDP.
Palavras-chave

Responsabilidade social corporativa.

Estrutura de capital.

Capital de terceiros.

Capital próprio.

$P I B$.
Article information

Received: August 24, 2020

Approved: April 12, 2021

Published: July 8th, 2021

\begin{abstract}
Companies are under external and internal pressure to adopt corporate social responsibility (CSR) practices. Positive and significant results of the relationship between CSR and financial performance are not always confirmed in empirical studies, demonstrating, thus, no consensus has been achieved in CSR literature yet. Thereby, we seek to understand the influence of capital structure on the performance of CSR practices, since there is a theoretical omission about intangible attributes. We formulated three hypotheses about the relationship between CSR and: the capital structure (H1); the debt financing (H1a); and the shareholder's equity (H1b). We used a sample of 1,642 publicly traded companies on the 10 highest GDP countries. Using GMM 2SLS estimator, the results reveal positive and significant relationship between shareholders' equity and CSR, while for the relationship between debt financing and CSR shown a negative and significative correlation. Our findings suggest that companies with higher scores of CSR tend to finance itself through equity. We found differences between countries related to the capital structure volume required to achieve a CSR positive index. Our findings provoke further debate concerning the reasons that conduct organizations to adopt such practices and foster new discussions about the aspects that involve social practices responsible adoption in companies.
\end{abstract}

\section{Resumo}

As empresas estão sob pressão externa e interna para adotar práticas de responsabilidade social corporativa (RSC). Resultados positivos e significativos da relação entre RSC e desempenho financeiro nem sempre são confirmados em estudos empíricos, demonstrando que ainda não há consenso na literatura. Desse modo, buscamos compreender a influência da estrutura de capital no desempenho das práticas de RSC, visto que há uma omissão teórica sobre os atributos intangíveis. Formulamos três hipóteses sobre a relação entre a RSC e: a estrutura de capital (H1); capital de terceiros (Hla); e capital próprio (H1b). Utilizamos uma amostra de 1.642 empresas de capital aberto dos 10 países com maior PIB. Por meio do estimador GMM 2SLS, os resultados revelam uma relação positiva e significativa entre o capital próprio e a RSC, ao passo que, entre o capital de terceiros e a RSC demonstra uma relação estatisticamente significativa, porém inversa. Nossos achados sugerem que as companhias com niveis altos de RSC tendem a se financiar por meio do capital próprio. Entre os países estudados, encontramos variações em relação ao volume da estrutura de capital necessário para atingir determinado indice positivo de RSC. Tais achados provocam debate sobre os motivos que conduzem as organizações a adotar essas práticas e fomentam novas discussões sobre os aspectos que envolvem a adoção de responsabilidade social corporativa.

\section{Practical implications}

This research contributes to improve the quality of decision-making processes by demonstrating the companies' capital structure, specifically, the fund-raising from shareholders' equity is influenced by the CSR practices. Besides, our financial model is useful to investors/shareholders to calculate the necessary investment to achieve an aimed CSR performance in distinct sectors.

Copyright (C) 2021 FEA-RP/USP. All rights reserved

Corresponding author: Tel. +55 (11) 98719-5419

E-mail: paula.pontes.campos@gmail.com (P. P. de Campos-Rasera); gabriela.abreu.passos@gmail.com (G. de A. Passos); rdcolauto.ufpr@gmail.com (R. D. Colauto)

Universidade Federal do Paraná, Setor de Ciências Sociais Aplicadas.Av. Prefeito Lothário Meissner, 632 - Campus III, Jardim Botânico - Curitiba/PR 80210070, Brazil. 


\section{INTRODUCTION}

There is still no consensus in literature about the determinants that lead companies to adopt corporate social responsibility (CSR) practices. From this restlessness, we propose to investigate the effects of capital structure influence on CSR of listed companies related to the world's 10 largest economies in 2019-2020. Prior studies revealed different explanations for the social responsibility practices implementation: it minimizes the firm's risk (Teixeira, Nossa \& Funchal, 2011); adds value to companies (Servaes \& Tamayo, 2013); reduces informational asymmetry (Cho, Lee \& Pfeiffer Jr., 2013); improves corporate reputation (Baraibar-Diez \& Sotorrío, 2018).

Notwithstanding that different topic have been researched, most of studies seek to relate CSR to Corporate Financial Performance (CFP); however, the results of these investigations differ from one another (McWilliams \& Siegel, 2000; Campbell, 2007; Carroll, 2008; Saeidi et al., 2015; Cantino, Devalle \& Fiandrino, 2017; Yang, He, Zhu \& Li, 2018).

Certain studies investigate the effects of CSR on CFP. Researchers found a positive and significative results in this correlation. For example, while analyzing Spanish companies, Rodriguez-Fernandes (2016) verified that corporate policies focused on responsible social actions improve positive financial returns, being the organizations that most invest, those with the highest financial returns; and, according to Wang and Sarkis (2017), the CSR-based management renders into greater financial results.

In turn, positive and significant results of the relationship between CSR and CFP are not always confirmed in empirical studies (McWilliams \& Siegel, 2000; Saeidi et al., 2015). Nollet, Filis and Mitrokostas (2016), whilst analyzing the companies that compose the S\&P 500 index, inferred that even CSR has a positive coefficient in relation to CFP, nevertheless not significant. Chen, Hung, and Wang (2018) found negative association in Chinese companies, denoting that companies with spending on CSR decreased profitability.

Such divergences in results, as already pointed out by McWilliams and Siegel (2000), are not surprising. Part of the problem lies in the econometric models' specification used and the other part exists in the fact that the theoretical omission CSR creates intangible attributes for the firm, such as reputation, legitimacy, and reliability. Therefore, these other elements suggest that the relationship between CSR and CFP is more complex than is usually addressed in studies and that, actually, it does not occur directly (Saeidi et al., 2015).

In this perspective, a group of researchers argues that CFP would only be a consequence of the association between CSR and corporate capital structure (Teixeira et al., 2011; Almeida \& Santos, 2016; Yang et al., 2018; Hamrouni, Boussaada \& Toumi, 2019), which we also support in this research. This linkage results from change of thoughts, in which political and community forces seek convergence between financial and social goals (Campbell, 2007; Carroll, 2008; Chen et al., 2018). Thereby, the logic propagated worldwide is that companies should not only maximize the returns and defend shareholders', but also consider all stakeholders (Al-Dah, Dah \& Jizi, 2018; Baraibar-Diez \& Sotorrío, 2018).

The relevance of stakeholders to companies is noticeable since they validate CSR actions. Though, validation will only occur when such practices meet their expectations of what would be appropriate and acceptable. Given this fact, managers ponder the pressures received by the company for the implementation of responsible social practices (McWilliams, Siegel \& Wright, 2006; Hamrouni et al., 2019).

Researchers argue that CSR has, above all, a relationship with the capital structure of companies, since this arrangement represents the materialization of the stakeholders' influence on organizations (Yang et al., 2018; Hamrouni et al., 2019). This influence results from the operating activities' financing by debts contracting with its stakeholders. Thus, involvement with socially responsible actions impacts the access to finance by organizations, whether through equity or third parties (Almeida \& Santos, 2016; Hamrouni et al., 2019).

Accordingly, the organizations involvement in socially responsible actions would impact on access to funding for organizations, either through shareholders' equity or debt (Yang et al., 2018; Hamrouni et al., 2019). From shareholders' equity perspective, current shareholders search for organizations with CSR practices and, thus invest more resources in these companies (Teixeira et al., 2011). As far as debt is concerned, CSR actions lead to greater ease of access to debt contraction, since this behavior increases third-party reliability in the company (Almeida \& Santos, 2016; Hamrouni et al., 2019).

These contradictions in CSR literature let research such as ours demonstrate the relevance of studying the reasons that drive responsible social practices, as well as the related effect of capital structure on CSR. Our findings show that capital structure and shareholder's equity correlates positively with CSR performance, while the relation between debt and CSR performance is negative. Furthermore, the results demonstrate variations in different countries and sectors. 
These findings contribute with CSR literature by showing that the higher levels of transparency and disclosure of CSR practices boost investments and reliability from stakeholders, whereas the debt financing decreases due to investments on equity. We trust that this debate on the results can be helpful to other researchers obtain new insights into CSR practices.

\section{LITERATURE REVIEW AND HYPOTHESIS DEVELOPMENT}

Conceived as a global phenomenon, CSR marks a shift in thinking about what interests' companies should address (Carroll, 2008). It occurs because management focused exclusively on the interests of shareholders presents problems, as other stakeholders of the company that are important to its operation may be overlooked, such as the Government, Suppliers, Customers (Teixeira et al., 2011). As a consequence, the perspective shift from shareholders to stakeholders reinforces CSR's widespread view that all parts of the organization are important and should have their expectations met (Baraibar-Diez \& Sotorrío, 2018; Yang et al., 2018; Garcia, Mendes-da-Silva \& Orsato, 2019).

The duality between the shareholders and stakeholders' objectives does not cease to exist. Because of its importance, conscious companies tend to avoid actions that could harm their stakeholders, and if it does, they try to correct the incident and recover the damage (Campbell, 2007), due to the impact that other parties may have on the entity. Nevertheless, firms' goal remains to maximize shareholder wealth, even when facing increasing external pressures to meet social expectations (Al-Dah et al., 2018).

However, as a matter of fact, not all companies are on the same level of behavior and assimilation of responsible social practices. Carroll (2008) pointed out that there are differences in CSR levels from sector to sector, as responsibilities change. In McWilliams, Siegel \& Wright (2006) view, CSR demands vary by country, region, and industry. Similarly, Garcia et al. (2019) consider that these differences depend on economy characteristics in which companies are inserted, as well as from the different stages of economic development.

Hamrouni et al. (2019) emphasize that the implementation of CSR policies in organizations involves ethical, legal, sustainability and reputation aspects. Because of this, the top management of companies ponder the implementation of CSR, considering the distinct aspects and consequences that occurs by the adoption of this practice (McWilliams et al., 2006).

Pursuant this line of argument, responsible social practices are considered by companies, choosing the capital structure (Almeida \& Santos, 2016). Since the financing of operating activities comes from the contracting of external debts, the organizations take the decision between third parties or shareholders' equity. According to Yang et al. (2018), the capital structure affects decision making about CSR strategies, because the adoption of that corporate practice improves the environment and reduces part of the inherent business risks.

In relation to equity, Ferris, Javakhadze and Rajkovic (2017) argue that this group is constantly looking for investments that prove to be socially responsible. This engagement causes shareholders to put pressure on organizations to take up CSR-oriented practices. By means of CSR practices, the company's value increases, as it demonstrates a commitment to all stakeholders to improve the relationship between internal and external parts of the organization, which would encourage the shareholder to maintain or increase its capital in the entity, and also, would attract new investors (Cho et al., 2013; Borghesi, Houston \& Naranjo, 2014).

The third-party capital is composed by debts contracted by the companies for its operational leverage. The CSR practices promote the credit access since reduce information asymmetry issues and insolvency risks (Almeida \& Santos, 2016; Chen et al., 2018). Besides this, the ease on credit access also derives from the reputation generated by the CSR. Because of trust increasing between company and its creditors and thus, as a reward for high levels of CSR, there would be this easier access to debt taking (Hamrouni et al., 2019).

Hence, given the above, we formulate the following research hypothesis: (decreases).

H(1): The corporate social responsibility index is high (low) when corporate capital structure increases

H(1a): The corporate social responsibility index is high (low) when debt increases (decreases). (decreases).

H(1b): The corporate social responsibility index is high (low) when shareholders' equity increases 


\section{SAMPLE AND DATA}

Listed corporations of the 10 highest GDP countries in 2019, with CSR index represented by the ESG score (environment, social \& governance) provided by Thomson Reuters ${ }^{\circledR}$ database, for the 2010-2018 period, represent our sample for the study. According to the list released by the International Monetary Funds (IMF, 2019), the ten countries ranked globally with the highest GDP are: United States of America (US \$21,439 billion), China (US \$ 14,140 billion), Japan (\$ 5,154 billion), Germany (\$3,863 billion), India (\$2,963 billion), United Kingdom (\$ 2,744 billion), France (\$ 2,707 billion), Italy $(\$ 1,989)$ billion), Brazil (\$1,847 billion) and Canada (\$1,731 billion).

We adopted the cut from 2010 due to the availability of the ESG performance index on the Eikon platform (Thomson Reuters database) for publicly traded companies as well as the removal of financial sector companies, resulting in a total of 1,660 companies. From this total of 1,660 we excluded companies with negative equity, totaling in the final sample 1,642 companies represented by 14,370 observations, as per Table 1 .

Table 1. Data sample distributed between the 10 highest GDP countries by economic sectors

\begin{tabular}{cccccccccccc}
\hline Country & S1 & S2 & S3 & S4 & S5 & S6 & S7 & S8 & S9 & S10 & Obs. \\
\hline 1 USA & 249 & 891 & 321 & 475 & 556 & 879 & 809 & 475 & 464 & 331 & 5450 \\
2 CHI & 36 & 99 & 45 & 99 & 27 & 126 & 36 & 90 & 99 & 45 & 702 \\
3 JAP & 135 & 575 & 243 & 27 & 180 & 808 & 405 & 429 & 117 & 117 & 3036 \\
4 GER & 36 & 101 & 27 & - & 72 & 135 & 44 & 90 & - & 26 & 531 \\
5 IND & 42 & 36 & 62 & 18 & 27 & 47 & 27 & 45 & 9 & 54 & 367 \\
6 UK & 106 & 355 & 157 & 104 & 53 & 495 & 90 & 145 & 178 & 54 & 1737 \\
7 FRA & 99 & 117 & 45 & 45 & 27 & 170 & 36 & 36 & 45 & 36 & 656 \\
8 ITA & 36 & 18 & 9 & 27 & - & 27 & - & 9 & - & 63 & 189 \\
9 BRA & 18 & 18 & 36 & 9 & 9 & 36 & 9 & 63 & - & 45 & 243 \\
10 CAN & 88 & 97 & 81 & 369 & 35 & 179 & 45 & 362 & 112 & 91 & 1459 \\
\hline Obs. Total & 845 & 2307 & 1026 & 1173 & 986 & 2902 & 1501 & 1744 & 1024 & 862 & 14370 \\
\hline
\end{tabular}

Source: research data.

Note. USA (United States of America), CHI (China), JAP (Japan), GER (Germany), IND (India), UK (United of Kingdom), FRA (France), ITA (Italy), BRA (Brazil) and CAN (Canada); S1 (Communication Services), S2 (Consumer Discretionary), S3 (Consumer Staples), S4 (Energy), S5 (Health Care), S6 (Industrials), S7 (Information Technology), S8 (Materials), S9 (Real Estate) and S10 (Utilities).

The sample of 1,642 companies is composed by ten economic sectors: industrials (331), consumer discretionary (265), materials (201), information technology (171), energy (135), consumer staples (117), real estate (116), health care (111), communication services (98), and utilities (97), distributed among the ten highest 2019 GDP countries: United States of America (632), China (78), Japan (338), Germany (60), India (42), United Kingdom (201), France (73), Italy (21), Brazil (27) and Canada (170).

\section{RESEARCH DESIGN}

\section{Corporate social responsibility}

To measure corporate social responsibility performance, we used the ESG score provided by Thomson \& Reuters as a proxy. The ESG score is an index obtained by weighing three pillars of sustainability: $34 \%$ represents the environmental pillar, $35.5 \%$ the social pillar and $30.5 \%$ the governance pillar. Through enterprise-level data capture, about 400 ESG metrics are calculated, of which a subset of 178 comparable and relevant industry measures are selected. Subsequently, these measures are classified into 10 categories, which, in turn, are weighted in their respective pillars (environmental, social and governance) and finally constitute the final ESG index. The Environmental Pillar was obtained by three categories: resource use, emissions, and innovation. Four categories derive from the Social Pillar: workforce, human rights, community, and product responsibility. The Governance Pillar involves three categories: management, shareholders, and CSR strategy (Thomson, 2019). 


\section{Capital structure}

Despite the different proxies utilized in research to represent the capital structure, we understand that this is an assemble of capital selected by the company to make investments, which involves both shareholders' equity and third-party capital. Hence, in this paper, we used as a variable for capital structure the sum of long-term debt (third-party capital) with shareholders' equity (equity) divided by total assets; for debt financing the sum of long-term plus short-term debt divided by total assets and, for equity financing the shareholders' equity. In this context, it is also important to highlight that we are investigating the influence of capital structure on CSR and not determining the factors influencing structure, a point that is not the subject of our discussion (Hamrouni et al., 2019).

\section{Control variables}

Large corporations are prone to diversification in the capital structure choice and, thus, have lower risks to bankruptcy, besides the advantage in accessing the credit market over smaller corporations (Rajan \& Zingales, 1995). Another interpretation refers to the ownership and control of large companies, that is, they dilute the ownership and have less control over management decision making, so the Board of Directors tends to prefer larger debts to control management (Bartholdy \& Matthew, 2006). In relation to ESG indices, the size and time of incorporation of the company have a positive relationship with CSR, as it mainly determines the availability and resources to obtain data and information to measure the sustainability performance of a company (Drempetic, Klein \& Zwergel, 2019). In this study, we use the natural log of Total Revenue [ln (TR)] as the company size proxy and [IPO_date], the time since the initial public offering (IPO), as the company age proxy. Therefore, we consider that the larger the size and age of the corporation, the greater the CSR investment.

In discussing the relationship between corporate social responsibility and corporate market value, Aouadi and Marsat (2018) reveal that a high ESG ratio affects market value for large companies, because CSR performance increases the perception of the company's value by stakeholders and has a direct and negative effect on operating cash flows, increasing costs or decreasing revenues, leading to lower operating performance. They demonstrate the result achieved through the visibility developed by the companies. We measure the Market Value of a company by multiplying its outstanding shares by its current market price and use as a proxy for operating cash flow ratio (FCO), operating cash flow divided by current liabilities. In this manner, we believe that a high performance of CSR increases the market value and decreases the operating cash flow.

The market positively and significantly values environmental practices carried out by companies not related to environmentally sensitive industries. In counterpoint, the market positively and significantly values the practices of social and corporate governance performed by companies belonging to these sensitive sectors. The results show that shareholders in sensitive sectors are especially concerned about environmental practices although are already reflected in stock prices. On the other hand, unexpected information about CSR practices is what generates significant added value (Miralles-Quirós et al., 2019). Thereby, the book value is also a specific proxy of the firm's value by stakeholders. This value perception attributed beget ingress of financial resources and, this way, we consider that book value increase grows CSR performance because of the bigger cash available. We use the book value per ordinary share (BVOS) to calculate the value per share of a company based on the company's net worth.

Trade-off theory suggests that companies use tangible assets as collateral to provide creditors with security in the event of financial difficulties. Jensen and Meckling (1976) sustain that guarantees protect creditors from the moral hazard problem caused by the conflict between shareholders and creditors. Williamson (1988) argues that the financing of capital projects depends on the tangibility of assets, since it consists of debt collateral, what generally reduces the lender's risk. Titman and Wessels (1988), Rajan and Zingales (1995) and Chen (2004) reported significant positive relationships between asset tangibility and a company's debt structure. Thus, companies with higher debt, would have greater tangibility. In this paper, we consider that the debt's corporation increase the CRS investment and, consequently, the CRS performance. In this perspective, the greater tangibility, the more the CRS performance. We define the tangibility of assets as the ratio of fixed assets to total assets.

Several studies have already analyzed the relationship between corporate social responsibility and corporate performance and although these studies indicate a positive relationship, certain findings are contradictory, as they reveal negative or meaningless positions and various causalities. Wu (2006) explains that these heterogeneous results originate from several measurements for corporate responsibility and corporate performance variables. 
CSR can be measured by various indicators such as the integrated reporting, Global Reporting Initiative (GRI), ESG index, whilst for corporate performance the accounting variables ROA, ROE or market-based Tobin's $\mathrm{Q}$ can be used. Despite the divergent results on the relationship between CSR and CFP, we understand that companies with greater CSR performance would have greater financial performance. This result is an indirect achievement of the relationship between the capital structure and CSR. As seen in the theoretical framework, CSR practices attract greater resources for the company, which increases the capital structure, but also increases the availability of resources for investment in other parts of the company that lead to increased financial performance. In this study, in addition to ROA, we use ROE calculated by the ratio of net income to shareholders' equity.

To specify the model, we introduced dummies variables for economic sectors as well as countries to adequately represent the differential effects produced by these economic agents' behavior due to the spatial character of the country variable, and the qualitative character of the economic sector variable. In the econometric model specified for this study, when combining dummies of different categories and quantitative variables, we incorporate changes in the intercept and function slope to enable the structural changes identification (Missio \& Jacobi, 2007). This evidence is shown in Figure 1 and Figure 2 at 6.3 Hypothesis (1b): The effect of Shareholder's Equity on CSR, in addition to the results in Table 4.

One of the important aspects to consider in estimating econometric models between CSR and CFP is to include time intervals between regressors of at least one year, given that corporate social responsibility will not affect company performance at one go. Moreover, we include a cause-and-effect analysis in the model, as there may be a reverse causality situation between CSR and capital structure.

\subsection{Econometric model}

Based on the literature review, the analysis of the relationship between capital structure and corporate social responsibility of this study will be developed through the econometric models evidenced in equations (1), (1a) and (1b):

$$
\begin{gathered}
\text { CRS }_{i, t}=\beta_{0}+\beta_{1} \text { CapStr }_{i, t}+\beta_{2} \text { Instrumental }_{i, t-2}+\sum_{(k=3)}^{8} \delta_{k} \text { Controls }_{k, t}+\beta_{11} \text { Sector }_{i, t}+\beta_{12} \text { Country }_{i, t}+\mu_{i, t} \\
\text { CRS }_{i, t}=\beta_{0}+\beta_{1} \text { Debt }_{i, t}+\beta_{2} \text { Instrumental }_{i, t-2}+\sum_{(k=3)}^{8} \delta_{k} \text { Controls }_{k, t}+\beta_{11} \text { Sector }_{i, t}+\beta_{12} \text { Country }_{i, t}+\mu_{i, t} \\
\text { CRS }_{i, t}=\beta_{0}+\beta_{1} \text { Equity }_{i, t}+\beta_{2} \text { Instrumental }_{i, t-2}+\sum_{(k=3)}^{8} \delta_{k} \text { Control }_{k, t}+\beta_{11} \text { Sector }_{i, t}+\beta_{12} \text { Country }_{i, t}+\mu_{i, t}
\end{gathered}
$$

Where corporate social responsibility (CSR) is represented by the ESG (environmental, social and governance) index; capital structure evidenced by third-party capital (long-term debt) and shareholders' equity (equity); instrumental variable represented by the lag of two periods of the capital structure given the issue related to the presence of endogeneity; control variables (size, age, market value, operating cash flow, tangibility, return on assets, return on equity and book value per share); and, dummy variables for sector and country.

The parameters of this model are estimated using OLS, but inference requires a correlation control within the error $\mu(\mathrm{i}, \mathrm{t})$ for a given individual, one being constructed using robust standard errors or grouped at the individual level. Due to the invalidity on the non-correlation premise, one or more regressors are endogenous, causing bias in the estimators and mistaken inferences. Endogeneity issues typically arise for three reasons: omitted variables, regressor measurement errors, and/or simultaneity (Ketokivi \& McIntosh, 2017).

The purpose of this study was to examine the relationship between corporate social responsibility and capital structure using a dynamic panel estimator (GMM), which eliminates the main sources of endogeneity inherent in the proposed relationship estimation, according to studies by Wintoki, Linck and Netter (2012).

\section{DESCRIPTIVE ANALYSIS}

The data on Table 2 evince the highest values of CSR, equity and debt of companies distributed by economic sector on each country. Analyzing by sectors, we note the following the higher performance of CSR on communication services (S1) correspond to French companies, on consumer discretionary (S2) to German companies, on consumer staples (S3) to American companies, on energy (S4) to Canadian companies, on health care (S5) to UK's companies, on industrials (S6) to German companies, on information technology (S7) to American companies, on materials (S8) to Japanese companies, on real estate (S9) to American companies and on utilities (S10) to Italian companies. 
Regarding the higher values of equity, we have on communication services (S1) correspond to Japanese companies, on consumer discretionary (S2) to German companies, on consumer staples (S3) to American companies, on energy (S4) to UK companies, on health care (S5) to American companies, on industrials (S6) to UK companies, on information technology (S7) to Japanese companies, on materials (S8) to Canadian companies, on real estate (S9) to UK companies and on utilities (S10) to Indian companies.

At last, in relation to the higher values of debt, we have on communication services (S1) correspond to American companies, on consumer discretionary (S2) to Brazilian companies, on consumer staples (S3) to American companies, on energy (S4) to UK companies, on health care (S5) to Canadian companies, on industrials (S6) to American companies, on information technology (S7) to American companies, on materials (S8) to UK companies, on real estate (S9) to American companies and on utilities (S10) to Japanese companies.

Table 2. Cross-data between companies of the 10 highest GDP countries and economic sectors

\begin{tabular}{|c|c|c|c|c|c|c|c|c|c|c|c|}
\hline Country & S1 & S2 & S3 & S4 & S5 & S6 & S7 & S8 & S9 & S10 & ST \\
\hline $1 \mathrm{USA}$ & $\mathrm{D}$ & & $\mathrm{C} / \mathrm{E} / \mathrm{D}$ & & $E$ & $\mathrm{D}$ & $\mathrm{C} / \mathrm{D}$ & & $\mathrm{C} / \mathrm{D}$ & & 6 \\
\hline $2 \mathrm{CHI}$ & & & & & & & & & & & - \\
\hline 3 JAP & $\mathrm{E}$ & & & & & & E & $\mathrm{C}$ & & $\mathrm{D}$ & 4 \\
\hline 4 GER & & $\mathrm{C} / \mathrm{E}$ & & & & $\mathrm{C}$ & & & & & 2 \\
\hline 5 IND & & & & & & & & & & $\mathrm{E}$ & 1 \\
\hline $6 \mathrm{UK}$ & & & & $\mathrm{E} / \mathrm{D}$ & $\mathrm{C}$ & $\mathrm{E}$ & & $\mathrm{D}$ & E & & 5 \\
\hline 7 FRA & $\mathrm{C}$ & & & & & & & & & & 1 \\
\hline 8 ITA & & & & & & & & & & $\mathrm{C}$ & 1 \\
\hline 9 BRA & & D & & & & & & & & & 1 \\
\hline $10 \mathrm{CAN}$ & & & & $\mathrm{C}$ & $\mathrm{D}$ & & & $\mathrm{E}$ & & & 3 \\
\hline
\end{tabular}

Source: research data.

Note. USA (United States of America), CHI (China), JAP (Japan), GER (Germany), IND (India), UK (United of Kingdom), FRA (France), ITA (Italy), BRA (Brazil) and CAN (Canada); S1 (Communication Services), S2 (Consumer Discretionary), S3 (Consumer Staples), S4 (Energy), S5 (Health Care), S6 (Industrials), S7 (Information Technology), S8 (Materials), S9 (Real Estate), S10 (Utilities) and ST (Sector total). Letter (C) correspond to ESG index; letter (E) to Equity; and letter (D) to Debt.

When crossing the data from CSR indexes, equity, and debt values between countries by economic sectors, the sectors that show the highest performance in CSR are information technology (S7) companies of United States, Germany, and India, followed by communication services (S1) French companies and German industrials (S6). Whereas the highest equity values are present in the materials (S8) sector in Canadian companies, followed by German consumer discretionary (S2) companies and UK energy (S4) sector companies. As for debt, the sectors that demonstrate the highest values are Brazilian and American consumer discretionary (S2) companies, followed by UK energy (S4) companies and American real estate (S9).

In particular, we also note that among the values of the CSR indexes, equity and debt, Chinese companies of the ten sectors presented did not reveal high levels in these variables, despite China being the second place in the ranking of the ten countries with the highest GDP in the world in 2019.

According to Table 3, the median ESG score is 56.52, which represents the central proxy measure used as RSC. Considering that the ESG index has a scale from 0 to 100, we understand the median value 56.52 of the sample is in the data's middle, that is, at least half of the observations are less than or equal to it, and at least half are greater or equal to it. Therefore, despite the amplitude of 90.63 in the ESG score observations, we can note that the CSR practices of companies in sample have not yet been widely implemented. In other words, these companies have not yet fully developed these actions.

Although there have been changes in thinking resulting from the spread of CSR in recent years, as commented by some researchers (Carroll, 2008; Baraibar-Diez \& Sotorrío, 2018; Yang et al., 2018; Garcia et al., 2019), we believe that this behavior stage occurs, since we are in a process of change, it has not completed entirely. Thus, we expect that in the coming years the CSR practices median of companies around the world may increase as the responsible social actions are more assimilate in the corporate environment. 
Table 3. Descriptive statistics of variables

\begin{tabular}{lcccccc}
\hline \multicolumn{1}{c}{ Variable } & Observations & Mean & Median & Coef. Var. & Min & Max \\
\hline ESG_Score & 14,370 & 55.34 & 56.52 & 0.32 & 7.27 & 97.90 \\
Capital structure & 14,370 & 0.69 & 0.71 & 0.23 & 0.02 & 8.60 \\
Equity & 14,370 & 0.43 & 0.42 & 0.44 & 0.00 & 1.03 \\
Debt & 14,370 & 0.26 & 0.25 & 0.70 & 0.02 & 8.18 \\
Size & 14,370 & 22.21 & 22.20 & 0.07 & 9.47 & 26.89 \\
Age & 14,370 & 11,109 & 8,459 & 0.74 & 14.00 & 53,525 \\
Market value & 14,370 & 1.16 & 0.78 & 1.53 & 0.01 & 78.17 \\
Operating cash flow & 14,370 & 0.01 & 0.02 & 6.64 & -1.27 & 1.72 \\
Tangibility & 14,370 & 0.63 & 0.64 & 0.35 & 0.001 & 1.00 \\
ROA & 14,370 & 0.12 & 0.11 & 0.79 & -0.61 & 3.21 \\
ROE & 14,370 & 0.48 & 0.28 & 7.22 & -3.21 & 262.75 \\
Book value per share & 14,370 & 29.15 & 12.33 & 9.57 & 0.00 & 24,021 \\
\hline
\end{tabular}

Source: research data.

By the coefficient of variation, we notice that the dispersion of data variation concerning book value per share, ROE, free cash flow, market value in relation to its mean is higher than the others. Likewise, the dispersion of debt, age and ROA data is high, as it corresponds to a variation greater than $70 \%$. Regarding the ESG score, capital structure, equity and tangibility data, the dispersion occurs between $23 \%$ to $44 \%$, while the size data variability is low, presenting a dispersion of $7 \%$ in relation to its average. Therefore, we can infer that the capital structure and size data set are homogeneous with each other, while the other variables present a heterogeneous data set.

\section{RESULTS ANALYSIS}

Following the model's estimates presented in equations (1), (1a), (1b) and the following procedures for the short panel, it performs the first application using the POLS estimator. Observed by the tests applied after regression, there was not the presence of collinearity (VIF 1.56), however the residues were identified heteroscedasticity. Thus, it again uses the POLS method with robust clustered standard errors for heteroscedasticity correction.

However, considering that the dependent variable, the ESG score, presents continuity in time, i.e., past values explain present and future values, it is necessary to find a method that solves the issue of endogeneity. Consequently, we adopt the instrumental variables in the model, operating in the capital structure variable the lag of one and two periods in the dynamic specification. As an efficient proposal to solve, or at least reduce endogeneity problems, are used estimators known as GMM. The equations (1), (1a), (1b) results are provided in Table 4.

The GMM 2SLS estimator were applied in the regression model of equations (1), (1a) and (1b). The estimation results shown in Table 1, represented by its coefficients and significance values, differ between capital structure, debt and equity correlated to CSR (ESG score). 
Table 4. Estimation results on GMM 2SLS

\begin{tabular}{|c|c|c|c|c|c|c|}
\hline \multirow[t]{2}{*}{ Dependent variable } & \multicolumn{2}{|c|}{ ESG_Score } & \multicolumn{2}{|c|}{ ESG_Score } & \multicolumn{2}{|c|}{ ESG_Score } \\
\hline & Coef. & $\mathrm{P}$-value & Coef. & P-value & Coef. & P-value \\
\hline Capital Structure & $\begin{array}{c}8.219 * * * \\
(2.173)\end{array}$ & 0.000 & & & & \\
\hline Debt & & & $\begin{array}{c}-4.060 * * * \\
(1.290)\end{array}$ & 0.002 & & \\
\hline Equity & & & & & $\begin{array}{c}3.013 * * \\
(1.385)\end{array}$ & 0.030 \\
\hline Size & $\begin{array}{c}6.693 * * * \\
(0.132)\end{array}$ & 0.000 & $\begin{array}{c}6.644 * * * \\
(0.107)\end{array}$ & 0.000 & $\begin{array}{c}6.609 * * * \\
(0.124)\end{array}$ & 0.000 \\
\hline Age & $\begin{array}{c}4.140 * * * \\
(0.217)\end{array}$ & 0.000 & $\begin{array}{c}3 \times 10-4 * * * \\
(0.000)\end{array}$ & 0.000 & $\begin{array}{c}3 \times 10-4 * * * \\
(0.000)\end{array}$ & 0.000 \\
\hline Market value & $\begin{array}{c}1.110 * * * \\
(0.169)\end{array}$ & 0.000 & $\begin{array}{c}1.050^{* * *} \\
(0.165)\end{array}$ & 0.000 & $\begin{array}{c}1.090 * * * \\
(0.165)\end{array}$ & 0.000 \\
\hline Operating cash flow & $\begin{array}{c}-6.144 * * * \\
(1.797)\end{array}$ & 0.001 & $\begin{array}{c}-6.360^{* * *} \\
(1.748)\end{array}$ & 0.000 & $\begin{array}{c}-6.765^{* * *} \\
(1.815)\end{array}$ & 0.000 \\
\hline Tangibility & $\begin{array}{c}0.142 \\
(0.891)\end{array}$ & 0.873 & $\begin{array}{c}3.263 * * * \\
(0.808)\end{array}$ & 0.000 & $\begin{array}{c}2.391 * * * \\
(0.718)\end{array}$ & 0.001 \\
\hline ROA & $\begin{array}{c}-7.996^{* * *} \\
(3.017)\end{array}$ & 0.008 & $\begin{array}{c}-7.463 * * * \\
(2.871)\end{array}$ & 0.009 & $\begin{array}{c}-8.516^{* * *} \\
(2.958)\end{array}$ & 0.004 \\
\hline ROE & $\begin{array}{c}-0.043^{*} \\
(0.025)\end{array}$ & 0.091 & $\begin{array}{c}-0.044^{*} \\
(0.025)\end{array}$ & 0.075 & $\begin{array}{l}-0.036 \\
(0.025)\end{array}$ & 0.145 \\
\hline Book value per share & $\begin{array}{l}-0.001 \\
(0.001) \\
\end{array}$ & 0.113 & $\begin{array}{l}-0.001 \\
(0.001) \\
\end{array}$ & 0.182 & $\begin{array}{l}-0.001 \\
(0.001) \\
\end{array}$ & 0.171 \\
\hline Intercept & & & & & & \\
\hline USA & $-140.59 * * *$ & 0.000 & $-96.21 * * *$ & 0.000 & $-101.38 * * *$ & 0.000 \\
\hline $\mathrm{CHI}$ & $-13.146^{* * *}$ & 0.000 & $-13.251 * * *$ & 0.000 & $-13.276 * * *$ & 0.000 \\
\hline JAP & $-5.823 * * *$ & 0.000 & $-5.637 * * *$ & 0.000 & $-5.961 * * *$ & 0.000 \\
\hline GER & $6.512 * * *$ & 0.000 & $5.474 * * *$ & 0.000 & $5.633 * * *$ & 0.000 \\
\hline IND & $2.763 * * *$ & 0.000 & $3.141 * * *$ & 0.000 & $2.916 * * *$ & 0.000 \\
\hline UK & $10.510 * * *$ & 0.000 & $9.977 * * *$ & 0.000 & $10.150 * * *$ & 0.000 \\
\hline FRA & $10.116^{* * *}$ & 0.000 & $9.835^{* * *}$ & 0.000 & $9.840 * * *$ & 0.000 \\
\hline ITA & $12.522 * * *$ & 0.000 & $12.320 * * *$ & 0.000 & $12.156^{* * *}$ & 0.000 \\
\hline BRA & $7.843 * * *$ & 0.000 & $8.823 * * *$ & 0.000 & $8.404 * * *$ & 0.000 \\
\hline CAN & $3.972 * * *$ & 0.000 & $3.695 * * *$ & 0.000 & $3.784 * * *$ & 0.000 \\
\hline Sector & & & & & & \\
\hline Communication Services & & & & & & \\
\hline Consumer Discretionary & -0.151 & 0.797 & 0.235 & 0.686 & 0.012 & 0.984 \\
\hline Consumer Staples & 0.395 & 0.563 & 0.634 & 0.348 & 0.233 & 0.732 \\
\hline Energy & $3.686^{* * *}$ & 0.000 & $3.959 * * *$ & 0.000 & $3.697 * * *$ & 0.000 \\
\hline Health Care & $4.202 * * *$ & 0.000 & $4.878 * * *$ & 0.000 & $4.710 * * *$ & 0.000 \\
\hline Industrials & 0.288 & 0.616 & 0.465 & 0.420 & 0.365 & 0.528 \\
\hline Information Technology & $6.930 * * *$ & 0.000 & $7.463 * * *$ & 0.000 & $7.219 * * *$ & 0.000 \\
\hline Materials & $3.603 * * *$ & 0.000 & $4.134 * * *$ & 0.000 & $3.728 * * *$ & 0.000 \\
\hline Real Estate & $10.668^{* * *}$ & 0.000 & $11.909 * * *$ & 0.000 & $11.327 * * *$ & 0.000 \\
\hline Utilities & -0.001 & 0.999 & 0.100 & 0.887 & 0.003 & 0.997 \\
\hline
\end{tabular}


Table 4. Estimation results on GMM 2SLS (continued)

\begin{tabular}{|c|c|c|c|}
\hline Dependent variable & ESG_Score & ESG_Score & ESG_Score \\
\hline & P-value & $\mathrm{P}$-value & P-value \\
\hline Prob $>F$ & 0.000 & 0.000 & 0.000 \\
\hline $\begin{array}{l}\text { R-squared } \\
\text { Overidentification } \\
\text { Sargan statistic }\end{array}$ & 0.3615 & 0.3640 & 0.3649 \\
\hline Chi-sq (1) P-val & 0.265 & 0.675 & 0.475 \\
\hline
\end{tabular}

Source: research data.

Note. ***,**, * Indicate statistical significance at the 1 percent, 5 percent, and 10 percent levels, respectively USA - United States of America, CHI - China, JAP - Japan, GER - Germany, IND - India, UK - United of Kingdom, FRA - France, ITA - Italy, BRA - Brazil and CAN Canada.

\subsection{Hypothesis (1): The effect of capital structure on CSR}

The results show positive and statistically significant relationship between CSR (ESG_score) and Capital Structure as well as for the control variables: size, age, and market value of the company. As the Capital Structure is composed by Debt financing and Equity financing, these findings are consistent with the studies of Almeida and Santos (2016), who noted that companies with higher corporate social responsibility ratings have more debt financing. In highly leveraged companies, it can occur wealth transfers potentials from creditors to shareholders. Since the monitoring costs are higher for these companies, it is crucial to reduce these costs by means of relevant information disclosure in the annual reports (Jensen \& Meckling, 1976). In relation to equity financing, the higher score of CSR minimizes risks and informational asymmetry, promoting a reduction of equity costs due to the lower beta as the firm's stock volatility achieved. Therefore, the investment on equity increases as investors receive specific benefits from socially responsible investments.

Despite being statistically significant at $1 \%$ level, the parameters of operating cash flow (FCO) and ROA are negative. For Barnett (2007) this negative relation exists, since firms that invest in CSR are at a competitive disadvantage to firms that do not. In addition, the ROE's parameter result is also negative and statistically significant at $10 \%$ level. However, arouses attention that firms with higher CSR levels tend to have lower return on equity. Borghesi et al. (2014) argue that this result suggests that at the least CSR investments are not in shareholder's interests and may instead be motivated by either the manager's moral or career concerns. Once more, these findings provide some confirmatory evidence that CSR investments are not universally pursued solely for the benefit of shareholders. In turn, the statistical results between CSR (ESG_score) and control variables, tangibility, and book value per share, were not significant for this model.

By checking the signal results for the control variables of operating cash flow (negative), ROA (negative) and market value (positive), these findings are also consistent with the study by Aouadi and Marsat (2018). Their study revealed that large companies with amplified visibility and high ESG ratios have a positive correlation with market value and a negative effect on operating cash flows, increasing costs or decreasing revenues, and conducting to lower operating performance.

When comparing the results between countries by economic sectors, we note that among the economic sectors statistically significant, the communication services is the one needs more investment on Capital Structure, followed by materials, energy, health care, information technology and then real estate. Being also a difference within countries, that means, in order to achieve the performance equivalent to the CSR index of Italian companies, Chinese companies need to invest $20 \%$ to $22 \%$ more in capital structure, Japanese companies $14 \%$ to $16 \%$ more, American companies 10\% to 11\% more, Indian companies $8 \%$ more, Canadian companies $7 \%$ more, German companies 5\% more, Brazilian companies 4\% more, and French and UK Companies 2\% more.

\subsection{Hypothesis (1a): The effect of debt financing on CSR}

In this model, we can observe the influence of debt financing on CSR (ESG_score). Interestingly, the results reveal a negative parameter besides the significance at $1 \%$ level, which means an inverse relation between debt financing and CSR performance. Higher is the performance of CSR, less will be the debts contracted by the company. These results contrast the findings of Yang et al. (2018) and Hamrouni et al. (2019), which shown a positive and significant relationship between the CSR disclosure and access to debt financing. Even though a higher score of CSR promotes an ease access to credit, we can observe that the equity cost is less than debt. Consequently, due to lower costs companies prefer to finance itself through equity, resulting thus, a negative parameter for debt financing. 
The results also show that a company's size, age, market value and tangibility affect positively the CSR disclosures $(p>0.000)$. Normally, large firms are better known and hence more detailly inspected than small firms. Consequently, large firms confront more internal and external pressure to invest in CSP and usually, due to their size, have enough resources to do so (Al-Dah et al., 2018). Our findings related to companies' age are consistent with the study of Choi (1999). His study revealed that the age of corporation for Korean listed companies is related to quality of environmental disclosure. This may be due to the Theory of Legitimacy, which considers that the age of a corporation is related to its reputation and historical engagement in CSR activities. While for Borghesi et al., 2014, the positive result of market value might suggest that companies are looking at socially responsible investments much like they do all other investments. The CSR investments are undertaken, if create value for investors and/or if managers realize a personal benefit. To examine whether debt financing has an independent, direct impact on CSR, we therefore include the asset tangibility in our model. Our findings on tangibility are consistent with Chung, Elder and Kim (2010) because tangible assets' payoffs are easier to observe, reducing therefore asymmetric information issues.

In particular, we could note the negative correlation between CSP (ESG_score) and the performance variables, ROA, and ROE likewise the FCO. These results are similar to the study of Yang et al. (2018). The authors argue that, in general, companies from countries with high levels of sustainability performance find it harder to capitalize on CSR than others from countries with relatively low levels of CSR. We agree that, probably, this is one of the explanations for heterogeneous results in other studies that investigated the relationship between CSP and CSR index.

When comparing the results between countries by economic sectors, we note that there is a difference within countries. More precisely, in order to achieve the performance equivalent to the CSR index of Italian companies, Chinese companies need to invest $30 \%$ to $36 \%$ more in debt financing, Japanese companies $21 \%$ to $25 \%$ more, American companies $15 \%$ to $17 \%$ more, Indian companies $11 \%$ to $13 \%$ more, Canadian companies $10 \%$ to $12 \%$ more, German companies $8 \%$ to $10 \%$ more, Brazilian companies $4 \%$ to $5 \%$ more, and French and UK Companies 3\% more.

\subsection{Hypothesis (1b): The effect of shareholder's equity on CSR}

Following the results between CSR and Capital Structure, the findings between CSR and Equity also reveal a positive and statistically significant relationship, either for the control variables: size, age, market value and tangibility of the company. The outcomes of FCO and ROA are significant, respectively $\mathrm{p}>0.000$ and $\mathrm{p}>$ 0.004, whereas its parameters are negative.

Thought-provoking in our study are the parameters' results of debt and equity financing. The first one is negatively correlated to CSR practices and the second one has a positive correlation. Analyzing its coefficients and signals $(-4,060 ;+3.013)$, we can infer that, in order to companies have a consolidated reputation, the internal and external pressures act intensively to obtain an optimal score of environmental, social and governance (CSR practices). Thus, the effects of equity financing are positive on CSR practices due to reduction of risks, informational asymmetry, and costs of equity (Teixeira et al., 2011; Cho et al., 2013), provoking a decrease on debt financing, even if a high score of CSR foments an access to credit. Relevant and higher levels of transparency and disclosure of CSR practices boost investments and reliability from stakeholders, while the debt financing decreases due to equity growth investments.

For all ten countries, the results reveal statistical significance at the $1 \%$ level, while for economic sectors only energy, health care, information technology, materials and real estate sectors are statistically significant. Furthermore, the model developed by Allouche and Laroche (2005), when performing a meta-analysis in studies concerning the effects of CSR on CFP, demonstrate the relevance of identifying economic sectors and countries. Similarly, McWilliams et al. (2006) reveal the importance of the qualification of the country, region, and the business branch of companies in models with the CSR theme.

For comparison reasons between the effects of equity and debt financing, in Figure 1 and Figure 2, the graph shows the energy sector analysis for companies in China and Italy. 


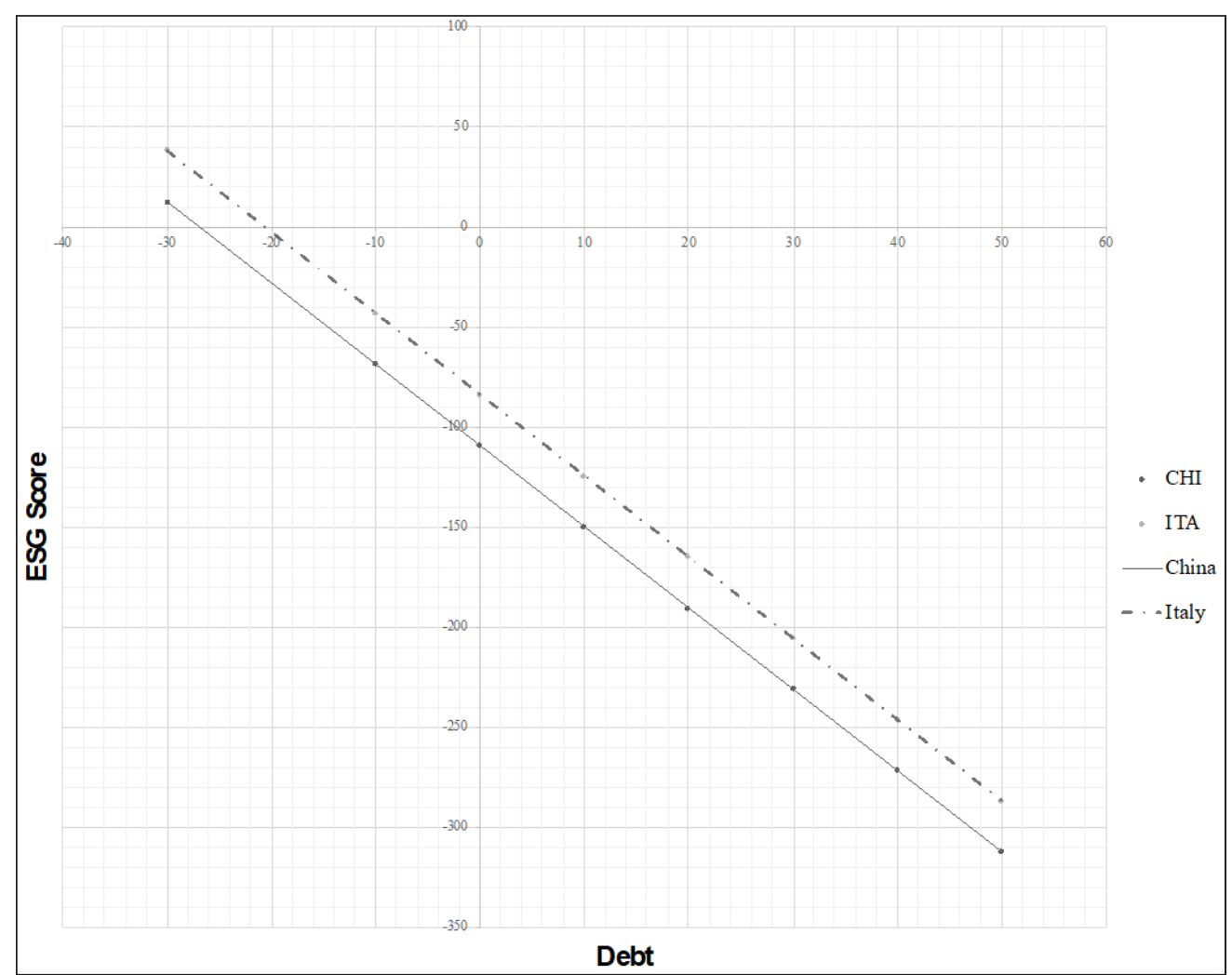

Figure 1. CSR index and Debt of China and Italy for energy sector Source: research data.

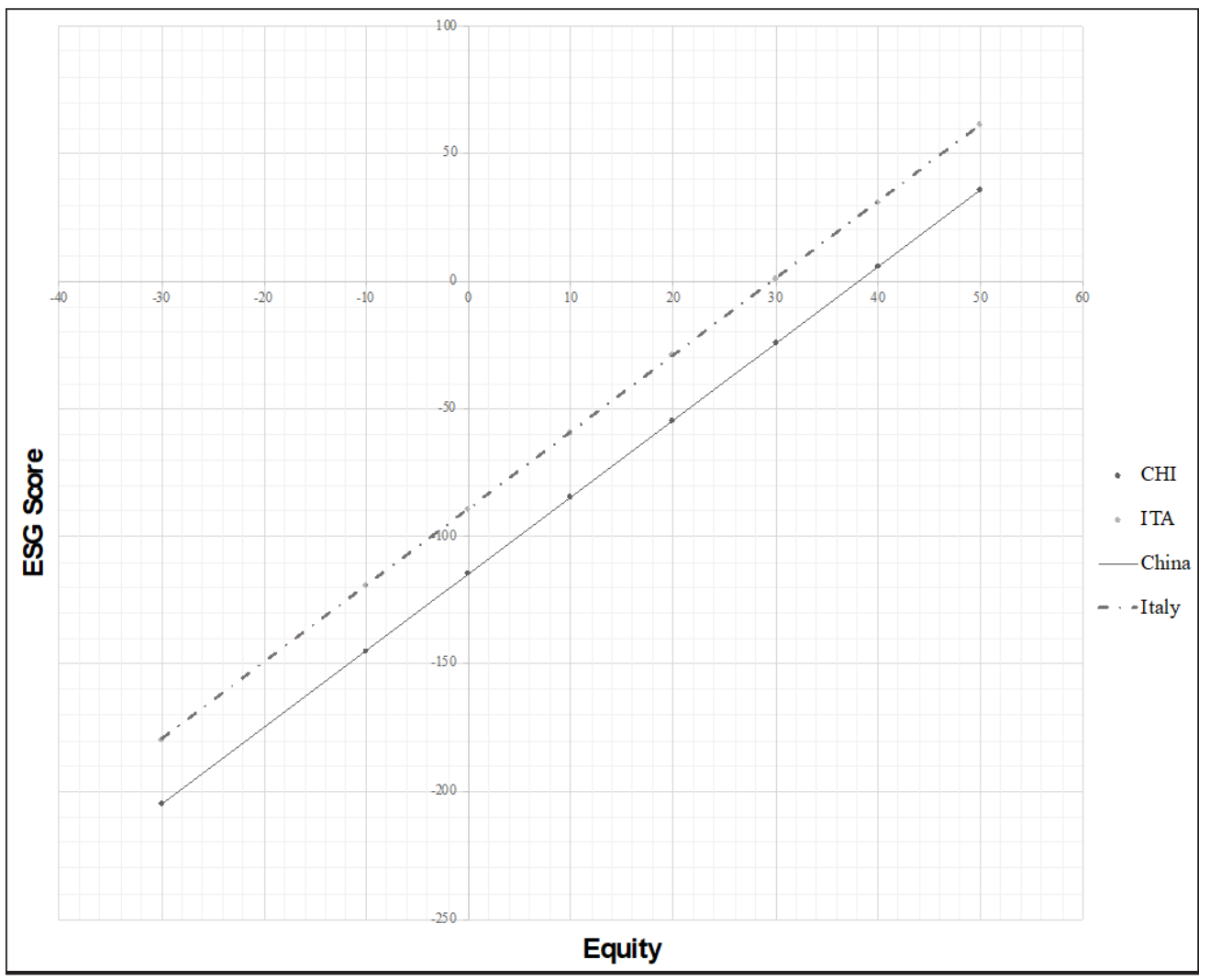

Figure 2. CSR index and Equity of China and Italy for energy sector Source: research data. 
In short, when observing both regression lines, we verify that to achieve a certain CSR index, Chinese energy companies need a larger equity financing than Italian companies as well its debt financing reduces more than Italian companies.

The graphs of Figure 3 and Figure 4 represent the economic sector of consumer discretionary and real estate distributed across the ten countries of this study. Each point indicated on the chart line shows the equity and debt financing correspondence for that sector.

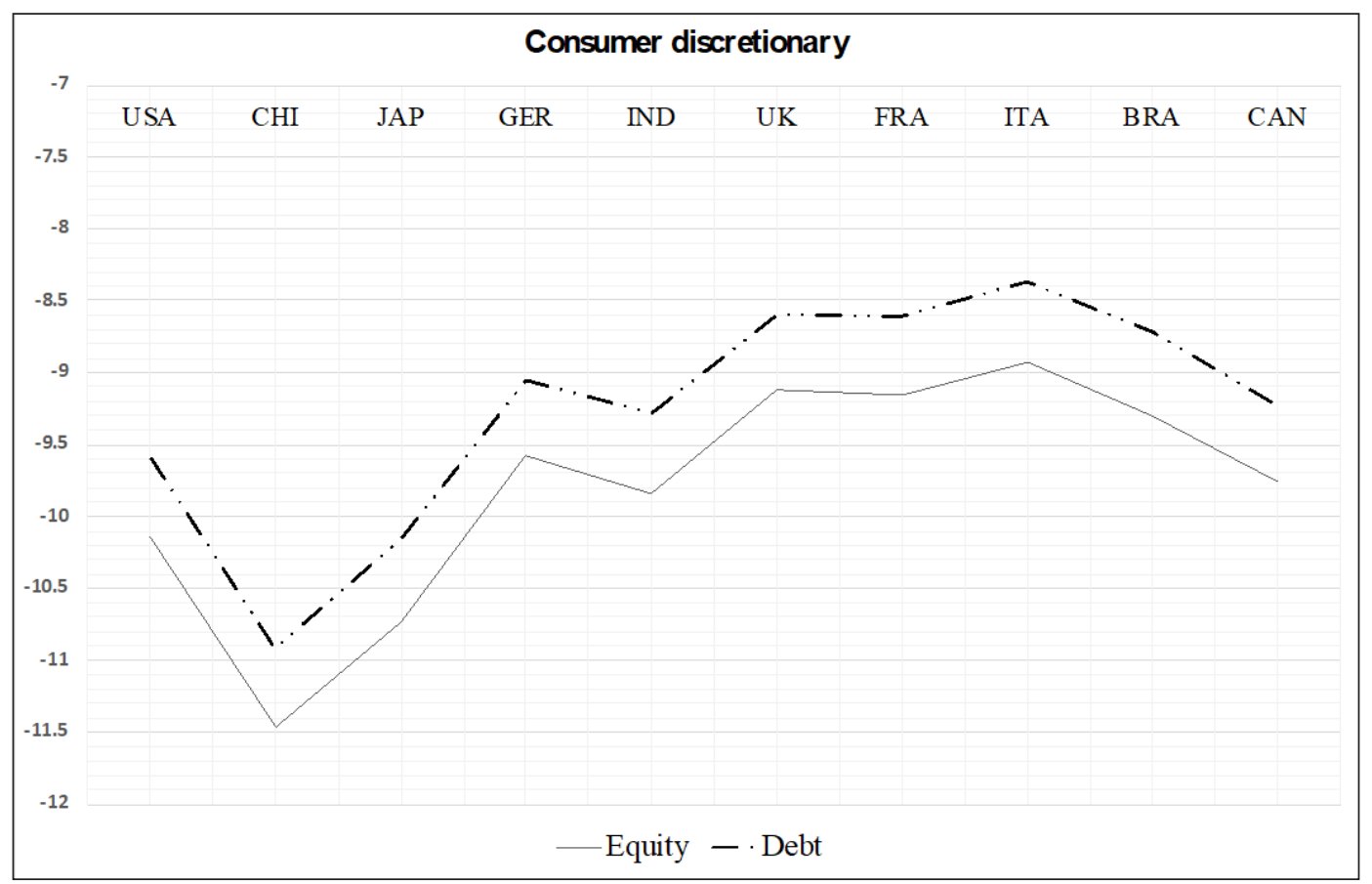

Figure 3. Consumer discretionary by countries on relevant Equity and Debt

Source: research data.

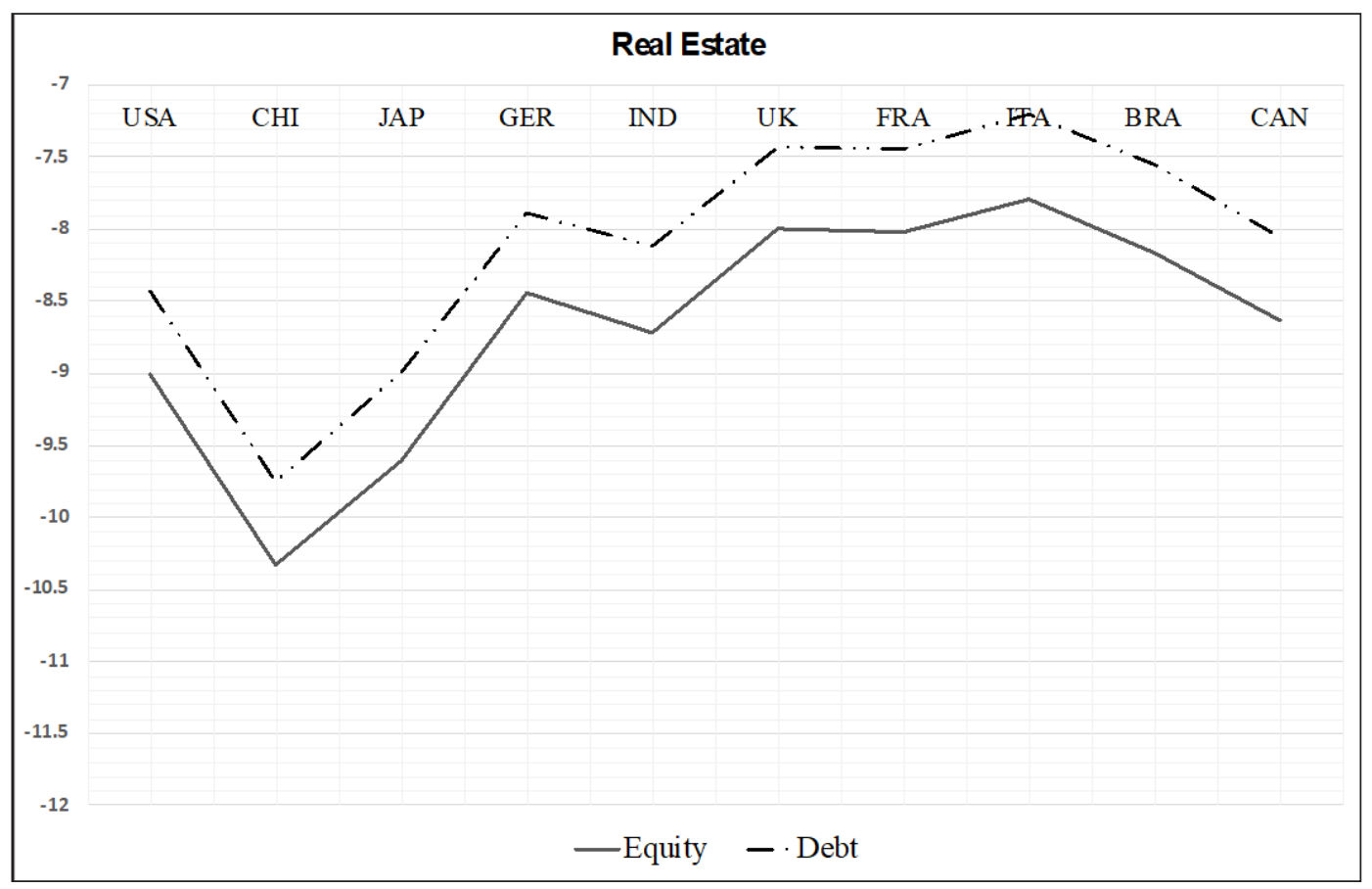

Figure 4. Real Estate by countries on relevant Equity and Debt Source: research data. 
The graphs presented show variation of consumer discretionary and real estate sectors for each country. We highlight that for China to achieve a positive CSR index, the contribution needed for investment in equity of its public enterprises is higher compared to other countries.

\section{SUMMARY AND CONCLUSIONS}

We verified that there is no evidence that conduct us to reject our hypothesis (1) and hypothesis (1b), and thereby, our findings reveal that capital structure and shareholder's equity correlates positively with CSR performance. However, our hypothesis (1a) related to the effects of debt financing on CSR, we have to reject it once our findings show a negative correlation. It is important to highlight that the variations found between countries, especially companies from nations with higher GDP, need a larger capital structure than smaller ones to obtain a positive CSR index. We believe this contrast is due to the companies' size, because of these ones are larger than those presents in countries of lowest GDP. As a consequence, the companies of the highest countries GDP need a larger capital structure to finance all of their operating activities, plus CSR actions.

In addition, other results deserve attention. First, we highlight that the financial performance variables of the model presented negative coefficients, which indicates that the expenses incurred to increase CSR performance does not generate returns. We make this observation due to the short-time period analyzed in this study. We also emphasize that CSR affects the company's reputation. This, in turn, is directly related to financial performance. However, it should be noted that corporate reputation derives from a process that does not occur overnight. Larger reason for inferring that CFP occurs in the long term. Thereby, we encourage further research to verify such relationships in a larger time frame.

Second, it concerns the divergence between the parameter signals of firm's market value and the book value per share as well as its significance, present only in market value. These results are not surprising, since the different purpose of each variable. The first reveals the value attributed by the market to the organization, and in counterpart, the second that displays the value based on the company's accounting. We understand that the positive and statistically significant findings in the relationship between market value and CSR index is due to the fact that CSR has an intangible asset in its constitution: the corporate reputation. Indeed, the market ponders CSR actions and judges whether they should be accepted. The result converges into the acceptance of these practices which generate a firm's value, justifying the positive and significant association.

In the meantime, the results have a close connection with the ESG score used as a proxy for CSR, which we consider a limitation of the study. Despite being a methodological choice, there are several indicators of CSR with different elements and weighting, thus, the results could differ one from another. In order to consolidate the results presented in this research, we encourage further research with different CSR indicators.

Beyond that, we would like to provoke a reflection. Are companies with leveraged capital structure more sustainable or just better disseminating CSR strategies? As with most CSR indexes, the ESG score is also based on disclosures of social, environmental and governance aspects. Though, what is publicized by companies actually performed by companies? Or is it just a window dressing to meet the demands and lessen the external pressures of society? We believe that the answers for these questions can be found in research that look inside companies.

We hope to contribute to the literature from the results obtained and the comments made. We seek to foster new discussions on the issues surrounding the adoption of socially responsible practices by companies from different corners of the world. We understand that the debate does not end in this paper, and it needs new voices and evidence, as we live in a society in constant change and, increasingly, new factors have influenced organizations.

\section{REFERENCES}

Al-Dah, B., Dah, M., \& Jizi, M. (2018). Is CSR reporting always favorable? Management Decision, 56(7), 15061525. https://doi.org/10.1108/MD-05-2017-0540

Allouche, J., \& Laroche, P. (2005). A meta-analytical investigation of the relationship between corporate social and financial performance. https://hal.archives-ouvertes.fr/hal-00923906/

Almeida, M. A., \& Santos, J. F. (2016). Capital structure and voluntary disclosure of information on corporate social responsibility in Brazilian companies. Revista de Ciências da Administração, 109-127. http://dx.doi. org/10.5007/2175-8077.2016v18n45p109 
Aouadi, A., \& Marsat, S. (2018). Do ESG controversies matter for firm value? Evidence from international data. Journal of Business Ethics, 151(4), 1027-1047. https://doi.org/10.1007/s10551-016-3213-8

Baraibar-Diez, E., \& Sotorrío, L. L. (2018). O efeito mediador da transparência na relação entre responsabilidade social corporativa e reputação corporativa. Revista Brasileira de Gestão de Negócios, 20(1), 05-21. https:// doi.org/10.7819/rbgn.v20i1.3600

Barnett, M.L., 2007. Stakeholder influence capacity and the variability of financial returns to corporate social responsibility. Acad. Manag. Rev. 32, 794-816. https://doi.org/10.5465/amr.2007.25275520

Borghesi, R., Houston, J. F., \& Naranjo, A. (2014). Corporate socially responsible investments: CEO altruism, reputation, and shareholder interests. Journal of Corporate Finance, 26, 164-181. https://doi.org/10.1016/j. jcorpfin.2014.03.008

Campbell, J. L. (2007). Why would corporations behave in socially responsible ways? An institutional theory of corporate social responsibility. Academy of Management Review, 32(3), 946-967. https://doi.org/10.5465/ amr.2007.25275684

Cantino, V., Devalle, A., \& Fiandrino, S. (2017). ESG Sustainability and Financial Capital Structure: Where they Stand Nowadays. International Journal of Business and Social Science, 8(5), 116-126. http://hdl.handle. net/2318/1650869

Carroll, A. B. (2008). A History of Corporate Social Responsibility: Concepts and Practices. In Crane, A., McWilliams, A., Matten, D., Moon, J., \& Siegel, D. (eds.) The Oxford Handbook of Corporate Social Responsibility. Oxford University Press,19-46.

Chen, Y. C., Hung, M., \& Wang, Y. (2018). The effect of mandatory CSR disclosure on firm profitability and social externalities: Evidence from China. Journal of Accounting and Economics, 65(1), 169-190. https://doi. org/10.1016/j.jacceco.2017.11.009

Cho, S. Y., Lee, C., \& Pfeiffer Jr, R. J. (2013). Corporate social responsibility performance and information asymmetry. Journal of Accounting and Public Policy, 32(1), 71-83. https://doi.org/10.1016/j.jaccpubpol.2012.10.005

Choi, J. S. (1999). An investigation of the initial voluntary environmental disclosures made in Korean semi-annual financial reports. Pacific Accounting Review, 11(1).

Chung, K. H., Elder, J., \& Kim, J. C. (2010). Corporate governance and liquidity. Journal of Financial and Quantitative Analysis, 45(2), 265-291. DOI: https://doi.org/10.1017/S0022109010000104

Ferris, S. P., Javakhadze, D., \& Rajkovic, T. (2017). The international effect of managerial social capital on the cost of equity. Journal of Banking \& Finance, 74, 69-84. https://doi.org/10.1016/j.jbankfin.2016.10.001

Garcia A.S., Mendes-Da-Silva W., Orsato R.J. (2019) Corporate Sustainability, Capital Markets, and ESG Performance. In: Mendes-Da-Silva W. (eds) Individual Behaviors and Technologies for Financial Innovations (pp. 287-309). Springer, Cham.

Hamrouni, A., Boussaada, R., \& Ben Farhat Toumi, N. (2019). Corporate social responsibility disclosure and debt financing. Journal of Applied Accounting Research, 20(4), 394-415. https://doi.org/10.1108/JAAR-01-20180020

IMF (2019) - International Monetary Funds. Available at: https://www.imf.org/external/datamapper/NGDPD@, WEO/OEMDC/ADVEC/WEOWORLD

Jensen, M. C., \& Meckling, W. H. (1976). Theory of the firm: Managerial behavior, agency costs and ownership structure. Journal of financial economics, 3(4), 305-360. https://doi.org/10.1016/0304-405X(76)90026-X

Ketokivi, M., \& McIntosh, C. N. (2017). Addressing the endogeneity dilemma in operations management research: Theoretical, empirical, and pragmatic considerations. Journal of Operations Management, 52, 1-14. https:// doi.org/10.1016/j.jom.2017.05.001

McWilliams, A., \& Siegel, D. (2000). Corporate social responsibility and financial performance: correlation or misspecification? Strategic Management Journal, 21(5), 603-609. https://doi.org/10.1002/(SICI)10970266(200005)21:5\%3C603::AID-SMJ101\%3E3.0.CO;2-3

McWilliams, A., Siegel, D. S., \& Wright, P. M. (2006). Corporate social responsibility: Strategic implications. Journal of management studies, 43(1), 1-18. https://doi.org/10.1111/j.1467-6486.2006.00580.x 
Nollet, J., Filis, G., \& Mitrokostas, E. (2016). Corporate social responsibility and financial performance: A non-linear and disaggregated approach. Economic Modelling, 52, 400-407. https://doi.org/10.1016/j. econmod.2015.09.019

Rodriguez-Fernandez, M. (2016). Social responsibility and financial performance: The role of good corporate governance. BRQ Business Research Quarterly, 19(2), 137-151. https://doi.org/10.1016/j.brq.2015.08.001

Saeidi, S. P., Sofian, S., Saeidi, P., Saeidi, S. P., \& Saeidi, S. A. (2015). How does corporate social responsibility contribute to firm financial performance? The mediating role of competitive advantage, reputation, and customer satisfaction. Journal of Business Research, 68(2), 341-350. https://doi.org/10.1016/j.jbusres.2014.06.024

Servaes, H., \& Tamayo, A. (2013). The impact of corporate social responsibility on firm value: The role of customer awareness. Management Science, 59(5), 1045-1061. https://doi.org/10.1287/mnsc.1120.1630

Teixeira, E. A., Nossa, V., \& Funchal, B. (2011). O índice de sustentabilidade empresarial (ISE) e os impactos no endividamento e na percepção de risco. Revista Contabilidade \& Finanças, 22(55), 29-44. https://doi. org/10.1590/S1519-70772011000100003

Thomson \& Reuters (2019). Environmental, Social and Governance (ESG) Scores from Refinitiv. Available at: https://www.refinitiv.com/content/dam/marketing/en_us/documents/methodology/esg-scores-methodology. pdf

Wang, Z., \& Sarkis, J. (2017). Corporate social responsibility governance, outcomes, and financial performance. Journal of Cleaner Production, 162, 1607-1616. https://doi.org/10.1016/j.jclepro.2017.06.142

Wintoki, M. B., Linck, J. S., \& Netter, J. M. (2012). Endogeneity and the dynamics of internal corporate governance. Journal of Financial Economics, 105(3), 581-606. https://doi.org/10.1016/j.jfineco.2012.03.005

Yang, S., He, F., Zhu, Q., \& Li, S. (2018). How does corporate social responsibility change capital structure? AsiaPacific Journal of Accounting \& Economics, 25(3-4), 352-387. https://doi.org/10.1080/16081625.2017.135 4710

\section{How to cite this paper}

Campos-Rasera, P. P. de; Passos, G. de A.; \& Colauto, R. D. (2021). Does capital structure influence the performance of corporate social responsibility? An analysis in companies of the world's largest economies. Revista de Contabilidade e Organizações, 15:e174007. DOI: http://dx.doi.org/10.11606/issn.1982-6486. rco.2021.174007 